\title{
The Antinociceptive Effect of Lonchocarpus Araripensis Lectin is Mediated by Endocannabinoid Receptors
}

\author{
Renata Morais Ferreira Amorim ${ }^{1}$, Messias Vital de Oliveira ${ }^{2}$, Benildo \\ Sousa Cavada ${ }^{2}$, Kyria Santiago Nascimento ${ }^{2}$, Ana Maria S. Assreuy ${ }^{{ }^{*}}$ and \\ Alana de Freitas Pires ${ }^{3}$
}

${ }^{1}$ Instituto Superior de Ciências Biomédicas, Universidade Estadual do Ceará, Av. Dr. Silas Munguba, 1700, 60740-000 Fortaleza - CE, Brazil

${ }^{2}$ Departamento de Bioquímica e Biologia Molecular, Universidade Federal do Ceará, Campus do Pici, s/n; Bloco 907, CEP 60455-970, Fortaleza-CE, Brazil

${ }^{3}$ Centro de Ciências da Saúde, Campus Centro, Centro Universitário Estácio do Ceará, Rua Eliseu Uchoa Becco, 600, 60810-270, Fortaleza, CE, Brazil

E-mail: renatamorais_br@hotmail.com; messiassigma@gmail.com; bscavada@gmail.com; kyriasantiago@gmal.com; anassreuy@gmail.com; alana.pires@estacio.br

*Corresponding author details: Ana Maria Sampaio Assreuy, PhD. Phone: +55(85)31019919; Fax: +55(85)31019810; anassreuy@gmail.com

\begin{abstract}
The involvement of endocannabinoid receptors in the antinociceptive activity of Lonchocarpus araripensis lectin (LAL) was investigated in the model of carragenan-induced hypernociception. Swiss mice received LAL $(10 \mathrm{mg} / \mathrm{kg}$ ) by intravenous (i.v.) route $30 \mathrm{~min}$ before subcutaneous (s.c.) injection of carrageenan in the paws. Animals were treated with the antagonists of CB1 (AM251) or CB2 (AM630) cannabinoid receptors 30 min before the lectin. LAL inhibited the hypernociception induced by carrageenan $(1 \mathrm{~h}: 11.87 \pm 0.61 \mathrm{~g} ; 3 \mathrm{~h}: 9.7 \pm$ $0.70 \mathrm{~g}$ ). AM251 (1 h: $4.75 \pm 0.41 \mathrm{~g} ; 3 \mathrm{~h}: 4.5 \pm 0.53 \mathrm{~g}$ ) and AM630 ( $1 \mathrm{~h}: 5.67 \pm 0.56 \mathrm{~g} ; 3 \mathrm{~h}: 5 \pm 0.68 \mathrm{~g}$ ) reversed the inhibitory effect of LAL. The antinociceptive effect of Lonchocarpus araripensis lectin is mediated by endocannabinoid receptors.
\end{abstract}

Keywords: Dalbergieae lectin; hipernociception; cannabinoid receptors

\section{INTRODUCTION}

Lectins are considered a heterogeneous group of proteins that exhibit specific and reversible carbohydrate-binding activities with biochemical properties and that act as cell recognition elements in a wide range of biological systems [1].

The lectin isolated from Lonchocarpus araripensis (LAL), belonging to Dalbergieae tribe, recognizes and specifically binds to N-acetyl-D-glucosamin [2]. Several effects have already been evidenced for LAL, such as vasorelaxant [3], anti-inflammatory $[2,4]$, and antinociceptive $[5,6]$, also a protective effect on sepsis model [7]. In respect to the antinociceptive activity, LAL has a pleiotropic effect in several nociceptive pathways, being associated to the modulation of inflammatory and/or hypernociceptive mediators $[5,6]$. However, there are no studies regarding LAL antinociception in the cannabinoid system.

The involvement of the endocannabinoid system is also related to nociceptive pathways, being involved in the analgesic activity of drugs used to treat pain, such as paracetamol [8], indomethacin and ibuprofen [9].
Besides, agonists of cannabinoid receptors present inhibitory effect in animal models of pain $[10,11]$. CB1 receptors are expressed primarily in central and peripheral neurons, while CB2 receptors, mainly in immune cells [12, $13,14,15]$.

This study evaluated the participation of CB1 and CB2 cannabinoid receptors in the antinociceptive activity of the lectin isolated from Lonchocarpus araripensis seeds in the mice model of hypernociception.

\section{MATERIALS AND METHODS}

Lectin

LAL was isolated and purified from the extract obtained from Lonchocarpus araripensis BENTH seeds. belonging to the Dalbergieae tribe, the Papilionoideae subfamily and the Leguminosae family. by affinity and ion exchange chromatography [2].

\section{Drugs and reagents}

Lambda carrageenan was diluted in sterile saline $0.9 \%$ $\mathrm{NaCl}), \mathrm{AM} 251$ and AM630 were diluted in dimethyl sulfoxide (10\% DMSO). All drugs were purchased from Sigma (St. Louis, Missouri, USA). 


\section{Animals}

Swiss male mice (25-30 g) were maintained in adequate environmental conditions $(12 \mathrm{~h} / 12 \mathrm{~h}$ dark/white cycles, $25^{\circ} \mathrm{C}$ ), receiving water and food ad libitum. Experimental protocols were conducted according to international ethic principles (National Institute of Health - NIH no 85-23, revised in 2011) and approved by the Ethic Committee for the use of Experimental Animals of the State University of Ceará (CEUA/UECE no 2127461/2015)

\section{Hypernociception model: mechanical allodynia}

Animals were treated with LAL ( $10 \mathrm{mg} / \mathrm{kg}$ ) by intravenous (i.v.) route $30 \mathrm{~min}$ before intraplantar subcutaneous (s.c.) injection of carrageenan $(300 \mu \mathrm{g} / \mathrm{paw} / 50 \mu \mathrm{l})$. AM-251 (80 $\mu \mathrm{g} / \mathrm{paw})$ and AM-630 (25 $\mu \mathrm{g} / \mathrm{paw})$ were used as CB1 and CB2 cannabinoid receptor antagonists, respectively, $30 \mathrm{~min}$ before LAL.

Mice were individually placed in boxes of elevated wire mesh platforms to allow access to the ventral surface of hind paws, in which were applied 6 consecutive mechanical pressures, using a polypropylene tip $(0.5 \mathrm{~mm}$ diameter $)$ coupled to digital algesimeter. The paw withdrawal response (g) was determined before (basal value), 60 and 180 min after injection of carrageenan. The reduced intensity force required to evoke paw withdrawal is indicative of hypernociception [16].

\section{Statistical analysis}

Statistical differences were determined by analysis of variance (one-way ANOVA) followed by Bonferroni test. Parametric data was expressed as Mean \pm SEM ( $n=$ 8 /group). $\mathrm{P}<0.05$ was considered significant.

\section{RESULTS}

\section{AM251 and AM630 reverses LAL} antihypernociceptive effect

Carrageenan reduced the nociceptive threshold in response to mechanical stimulation of the animal paws at $1 \mathrm{~h}$ (carrageenan: $3.05 \pm 0.32 v s$. saline: $10.62 \pm 098 \mathrm{~g}$ ) and $3 \mathrm{~h}$ (carrageenan: $2.75 \pm 0.31 \mathrm{vs}$. saline: $9.37 \pm 0.41 \mathrm{~g}$ ) after its administration. LAL inhibited the hypernociception induced by carrageenan $(1 \mathrm{~h}: 11.87 \pm 0.61 \mathrm{~g} ; 3 \mathrm{~h}: 9.7 \pm 0.70$ g) and the previous administration of AM251 ( $1 \mathrm{~h}: 4.75 \pm$ $0.41 \mathrm{~g} ; 3 \mathrm{~h}: 4.5 \pm 0.53 \mathrm{~g}$ ) or AM630 ( $1 \mathrm{~h}: 5.67 \pm 0.56 \mathrm{~g} ; 3 \mathrm{~h}$ : $5 \pm 0.68 \mathrm{~g}$ ) reversed the inhibitory effect of LAL (Fig. 1).

\section{DISCUSSION}

The present study demonstrates that the lectin isolated from Lonchocarpus araripensis (LAL) inhibits the hypernociception induced by carrageenan in mice, an effect that was reversed by the pretreatment with antagonists of endocannabinoids receptors.
It has been previously shown that LAL reduces the hypernociception induced with initial and final mediators that participate in the carrageenan effect, such as TNF- $\alpha$ and PGE2, respectively [5]. Besides, LAL has a direct action on the nociceptor, preventing the development of the hypernociceptive state via decrease of total $\mathrm{Na}+$ current produced in rat dorsal root ganglion [5]. The present study demonstrates that the antinociceptive effect of LAL may have the participation of cannabinoid receptors, since previous treatment with the antagonists of AM251 (CB1) and AM630 (CB2) reversed the lectin antinociceptice effect. Some studies highlight the involvement of the endocannabinoid system in the analgesic activity of drugs widely used in the clinical practice to treat pain, like paracetamol [8], indomethacin and ibuprofen [9]. Also, it has already been demonstrated the role of endocannabinoids in the modulation of hypernociception by electrophysiological and behavioral aspects $[12,17,18,19$, 20]. CB1 agonists are known to inhibit membrane excitation and $\mathrm{Ca}^{2+}$ conductance and also to increase potassium conductance, inducing an antinociceptive effect [21], in addition to stimulate nitric oxide synthesis [22]. In this line, the LAL antinociceptive effect involves the activation of the L-arginine/NO/GMPc/K+ATP pathway [6] and the decrease in the total $\mathrm{Na}+$ current [5]. Moreover, CB2 agonists play an important role in the control of the inflammatory process, especially in the initial events that modulate the communication between endothelial cells and leukocytes, leading to inhibition of cell migration [23]. It is well demonstrated that lectins have been used as tools in the study of inflammatory processes as they have the capacity of reversible and specific binding to glycan structures present in the membranes of inflammatory cells $[24,25,26]$. In the other study, LAL presented antiinflammatory activity via lectin domain, inhibiting neutrophil migration to rat peritoneal cavity and modulating inflammatory mediators [2]. In fact, the antinociceptive effect of LAL was inhibited by the animal's pre-treatment with AM630, proposing that the lectin could be acting as a CB2 receptor agonist or leading to the increase of endocannabinoids synthesis. Therefore, the present study demonstrated, for the first time, the participation of the endocannabinoid system in the antinociceptive effect of LAL, however, there is a need to conduct further studies to better understand how this system are associated to the effect of this lectin.

\section{CONCLUSIONS}

In conclusion, the antinociceptive effect of the lectin isolated from

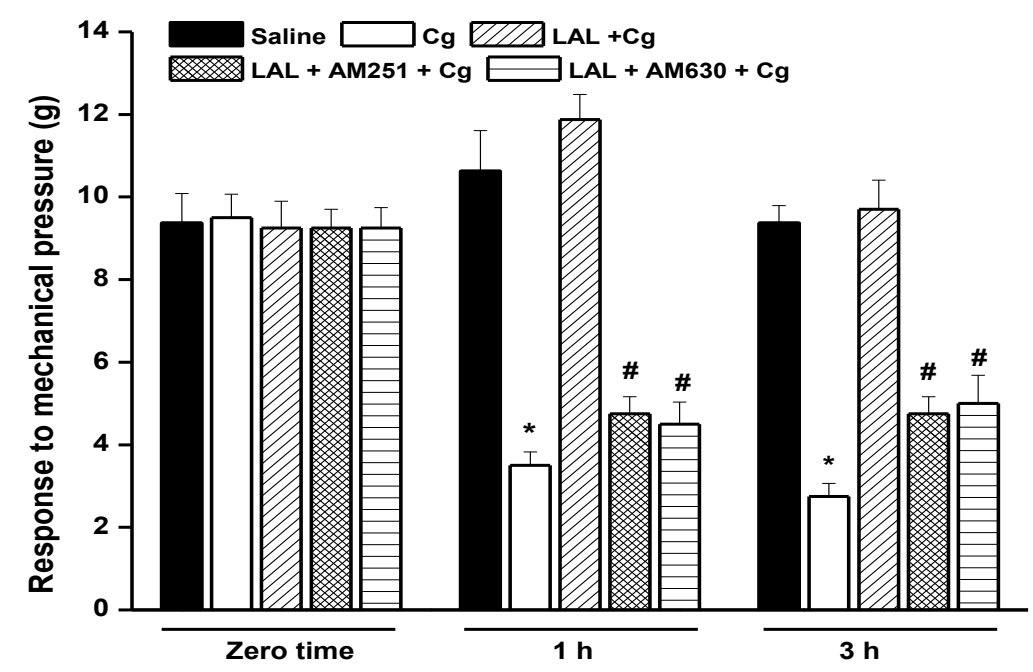

FIGURE 1: AM251 AND AM630 INHIBIT LAL ANTIHYPERNOCICEPTICE EFFECT. 
LAL $(10 \mathrm{mg} / \mathrm{kg}$ ) was administered i.v. $30 \mathrm{~min}$ before carrageenan (Cg: $300 \mu \mathrm{g} /$ paw; s.c.). Hypernociception was evaluated $1 \mathrm{~h}$ and $3 \mathrm{~h}$ after $\mathrm{Cg}$ administration by digital analgesimetry. AM251 (80 $\mu \mathrm{g} /$ paw; s.c.) or AM630 (25 $\mu \mathrm{g} /$ paw; s.c.) was administered $30 \mathrm{~min}$ before LAL. Mean \pm S.E.M. $(\mathrm{n}=6-8)$. One-way ANOVA/Bonferroni. ${ }^{*} \mathrm{p}<0.05$ vs. Saline; $\# \mathrm{p}<0.05$ vs. LAL.

Lonchocarpus araripensis seems to be mediated by endocannabinoid receptors.

\section{ACKNOWLEDGMENT}

The authors thank Conselho Nacional de Desenvolvimento Científico e Tecnológico-CNPq, Fundação Cearense de Amparo a Pesquisa-FUNCAP and Coordenação de Aperfeiçoamento de Pessoal de Nível Superior-CAPES. Cavada BS, Assreuy AM and Nascimento KS are senior investigators of CNPq.

\section{REFERENCES}

[1] Peumans, W.J., Van Damme, E.J.M. (1995). Lectin as Plant defense proteins. Plant Physiol. 109(2), 347352. DOI: $10.1104 /$ pp.109.2.347

[2] Pires, A.F., Rodrigues, N.V., Soares, P.M., Ribeiro, R.A., Aragão, K.S., Marinho, M.M., da Silva, M.T., Cavada, B.S., Assreuy, A.M.S. (2016). A novel N-acetyl glucosamine lectin of Lonchocarpols' araripensis attenuates acute cellular inflammation in mice. Inflamm Res.65, 43-52. DOI: 10.1007/s00011-015-0889-7.

[3] Pires, A.F., Almeida, L.M., Silva, D.H.M., Marques, G.F.O., Cajazeiras, J.B., Correia-Neto, C., Nascimento, K.S., Cavada, B.S., Assreuy, A.M.S. (2017). The lectin isolated from Lonchocarpus araripensis seed elicits endothelium- dependent vasorelaxation. J. Health Biol Sci. 5 (4) 306- 310. DOI:10.12662/23173076jhbs.v5i4. 1351.p306-310.2017.

[4] Pires, A.F., Marques, G.F.O., Alencar, N.M.N., Martins, M.G.Q., Silva, M.T.L.D., Nascimento, K.S.D., Cavada, B.S., Assreuy, A.M.S. (2019). Inhibitory effect of Lonchocarpus araripensis lectin in rat acute models of inflammation. An Acad Bras Cienc. 91(2), e20180991. DOI: 10.1590/0001-3765201920180991.

[5] Amorim, R.M.F., Pires, A.F., Santos-Nascimento, T.D., Cavada, B.S., Nascimento, K.S., Cajazeiras, J.B., LealCardoso, J.H., Mota, M.R., Assreuy, A.M. (2016). The leguminous lectin of Lonchocarpus araripensis promotes antinociception via mechanisms that include neuronal inhibition of $\mathrm{Na}+$ currents. Inflamm Res. 65, 701-708. DOI: 10.1007/s00011-016-0951-0.

[6] Assreuy, A.M.S., Amorim, R.M.F., Martins, S.L., Martins, M.G., Cajazeiras, J.B., da Silva, M.T.L., Pires, A.F., Nascimento, K.S., Cavada, B.S., Mota, M.R.L. (2020). Antinociceptive effect of Lonchocarpus araripensis lectin: activation of L-arginine/NO/cGMP/K+ATP signaling pathway. Inflammopharmacology. 28, 16231631. DOI: $10.1007 / \mathrm{s} 10787-020-00729-\mathrm{z}$.

[7] Assreuy, A.M.S., de Almeida, L.M., da Silva, D.H.M., Laranjeira, E.P.P, Rebouças, B.D.S., Cajazeiras, J.B., Nascimento, K.S., Cavada, B.S., Pereira, M.G., Pires, A.F. (2020). Protective effect of Lonchocarpus araripensis lectin in rat polymicrobial sepsis. Int. J. Dev. Res. 10, 40743-40748.

https://doi.org/10.37118/ijdr.19958.09.2020.

[8] Ottani, A., Leone, S., Sandrini, M., Ferrari, A., Bertolini, A. (2006) The analgesic activity of paracetamol is prevented by the blockade of cannabinoid CB1 receptors. Eur J Pharmacol. 531, 280-281. DOI: 10.1016/j.ejphar.2005.12.015.

[9] Holt, S., Paylor, B., Boldrup, L., Alajakku, K., Vandevoorde, S., Sundström, A., Cocco, M.T., Onnis, V., Fowler, C.J. (2007). Inhibition of fatty acid amide hydrolase, a key endocannabinoid metabolizing enzyme, by analogues of ibuprofen and indomethacin. Eur J Pharmacol. 565, 26-36. DOI: 10.1016/j.ejphar.2007.02.051.

[10] Richardson, J.D. (2000). Cannabinoids modulate pain by multiple mechanisms of actions. J Pain. 1, 2-14. DOI: 10.1016/bs.apha.2017.05.003.

[11] Piomelli, D. (2003). The molecular logic of endocannabinoid signalling. Nat Rev Neurosci. 4, 873884. DOI: $10.1038 / \mathrm{nrn} 1247$.

[12] Pertwee, R.G. (2001). Cannabinoid receptors and pain. Prog Neurobiol. 63, 569-611. DOI: 10.1016/s03010082(00)00031-9.

[13] Pertwee RG (2006). Cannabinoid pharmacology; the first 66 years. Br J Pharmacol 147: S163-S171. DOI: 10.1038/sj.bjp.0706406.

[14] Howlett, A.C. (2002). The cannabinoid receptors. Prostaglandins Another Lipid Mediat. 68, 619-631. DOI: 10.1016/s0090-6980(02)00060-6.

[15] Alexander, S.P.H., Mathie, A., Peters, J.A. (2008). Guide to Receptors and Channels (GRAC), 3rd edn. Br J Pharmacol 153 (Suppl. 2): S1-S209. DOI: 10.1038/sj.bjp.0707746.

[16] Cunha, T.M., Verri Jr, W.A., Vivancos, G.G., Moreira, I.F., Reis, S., Parada, C.A., Cunha, F.Q., Ferreira, S.H. (2004). An electronic pressure-meter nociception paw test for mice. Braz J Med Biol Res. 37, 401-407. DOI: 10.1590/s0100-879x2004000300017.

[17] Hohmann, A.G. (2002). Spinal and peripheral mechanisms of cannabinoid antinociception: behavioral, neurophysiological and neuroanatomical perspectives. Chem Phys Lipids. 121, 173-190. DOI: 10.1016/s0009-3084(02)00154-8.

[18] Clayton, N., Marshall, F.H., Bountra, C., O'Shaughnessy, C.T. (2002). CB1 and CB2 cannabinoid receptors are implicated in inflammatory pain. Pain. 96, 253-260. DOI: 10.1016/S0304-3959(01)00454-7.

[19] Kim, H.I., Kim, T.H., Shin, Y.K., Lee, C.S., Park, M., Song, J.H. (2005). Anandamide suppression of $\mathrm{Na}+$ currents in rat dorsal root ganglion neurons. Brain Res. 16, 3947. DOI: 10.1016/j.brainres.2005.09.004.

[20] Guindon, J., Hohmann, A.G. (2009). The endocannabinoid system and pain. CNS Neurol Disord Drug Targets. 8, 403-421. DOI: $10.2174 / 187152709789824660$.

[21] Howlett, A.C., Breivogel, C.S., Childers, S.R., Deadwyler, S.A., Hampson, R.E., Porrino, L.J. (2004). Cannabinoid physiology and pharmacology: 30 years of progress. Neuropharmacology; 47 (Suppl 1): 345-358. DOI: 10.1016/j.neuropharm.2004.07.030.

[22] Howlett, A.C., Mukhopadhyay, S. (2000). Cellular signal transduction by anandamide and 2arachidonoylglycerol. Chem Phys Lipids. 108, 53-70. 
[23] Gasperi, V.A., Evangelista, D.A., Chiurchiù, V.B.C., Florenzano, F.D., Savini, I.A., Oddi, S.B.C., Avigliano, L.A., Catani, M.V.A., Maccarrone, M. (2014). 2Arachidonoylglycerol modulates human endothelial cell/leukocyte interactions by controlling selectin expression through CB1 and CB2 receptors. The International Journal of Biochemistry \& Cell Biology. 51, 79-88. DOI: 10.1016/j.biocel.2014.03.028.

[24] Assreuy, A.M.S., Shibuya, M.D., Martins, G.J., Souza, M.L.P., Cavada, B.S., Moreira, R.A., Oliveira, J.T.A., Ribeiro, R.A., Flores, C.A. (1997). Anti-inflammatory effect of glucose-mannose binding lectins isolated from Brazilian beans. Mediators Inflamm.6 (3) 201-10. DOI: 10.1080/09629359791695.
[25] Napimoga, M.H., Cavada, B.S., Alencar, N.M., Mota, M.L., Bitencourt, F.S., Alves-Filho, J.C., Grespan, R., Gonçalves, R.B., Clemente-Napimoga, J.T., de Freitas A., Parada, C.A., Ferreira, S.H., Cunha, F.Q. (2007). Lonchocarpus sericeus lectin decreases leukocyte migration and mechanical hypernociception by inhibiting cytokine and chemokines production. Int Immunopharmacol. 7(6): 824-835. DOI: 10.1016/j.intimp.2007.02.001.

[26] Marques, G.F.O, Pires, A.F., Osterne, V.J.S., Pinto-Junior, V.R., Silva, I.B., Martins, M.G.Q., Oliveira, M.V., Gomes, A.M., de Souza, L.A.G., Pavão, M.S.G., Cavada, B.S., Assreuy, A.M.S., Nascimento, K.S. Vatairea guianensis lectin stimulates changes in gene expression and release of TNF- $\alpha$ from rat peritoneal macrophages via glycoconjugate binding. (2021). J Mol Recognit. Jun: e2922. DOI: 10.1002/jmr.2922. 